\title{
ARE TITLES OF BOOKS COPYRIGHT?
}

Previous to the existing Copyright Act of 1909 the statutes required, as a prerequisite to obtaining copyright, the deposit of a printed title on or before publication of the work, and the copyright began to run from the date of recording the title. From the importance thus given to filing the title, it became, and still continues, not uncommon for lawyers as well as laymen to speak loosely of "copyrighting" the title of a work. But more than this, we find in even so classic a treatise as George Ticknor Curtis' "Law of Copyright" the opinion expressed that if the registered title of a book is descriptive of its individuality, and if the effect of its subsequent adoption by another, even for a book wholly dissimilar in other respects, be to mislead the public in their purchases, "then there seems to be no good reason why it should not be regarded as an infringement of the copyright."

The notion, however, that the title is copyright separate and apart from the particular work it identifies, is directly contrary to the fundamental conception of copyright and to the uniform decisions of the courts. . The earliest reported case in which the question arose appears to be Jollie v. Jaques, ${ }^{2}$ which was an application for a preliminary injunction to restrain the defendant from an alleged violation of a copyright for a musical composition adapted from a German melody and published under the title "The Serious Family Polka". Some doubt was raised at the outset whether there was in the complainant's work such authorship as to entitle him to claim copyright at all, upon which the court directed an issue at law. But the complainant also argued that the title of his piece of music was original in the connection in which he applied it, and that, conceding the musical composition itself not to be within the protection of the copyright statute, still his prior registration entitled him to restrain the defendant from using the same title for another arrangement of the German melody. On this point, however, the court said:

\footnotetext{
2 At page 296.

1 Blatch. 618 (1852).

(646)
} 
"The right secured is the property in the piece of music, the production of the mind and genius of the author, and not in the mere name given to the work. This is, indeed, essential as well in taking out the copyright, as in identifying the composition. - . . But it is not the thing protected or intended to be protected...- The title or name is an apperidage to the book or piece of music for which the copyright is taken out, and if the latter fails to be protected, the title goes with it, 2s certainly as the principal carries with it the incident."

The leading case is Osgood v. Allen, in which the true principle is fully and admirably stated. This was a bill in equity to restrain the defendant from using the words "Our Young Folks" in the title of his periodical. The complainant had acquired a large circulation and valuable reputation for a monthly magazine, published at Boston, under the title "Our Young Folks, An Illustrated Magazine for Boys and Girls", and had duly registered each issue for copyright since 1864. Subsequently the defendant advertised and published at Augusta, Maine, a paper under the title, "Our Young Folks, Illustrated Paper". The two publications were in no respect similar except in the use of these words, "Our Young Folks," in the title of each. The complainant based his claim to relief, first, on the ground that his copyright gave him the sole right to use the title, and, secondly, on common law principles relating to the good will of trades and trade marks. On the latter point the court referred it to a master to ascertain and report on the fact whether or not the public were deceived or in danger of being deceived into the belief that the defendant's publication was the complainant's. On the question of copyright in the title, however, the court held that the complainant's contention was futile:

"The Constitution gives Congress power to promote the progress of science and the useful arts by securing to authors for limited times exclusive rights to their 'writings'. Congress has accordingly passed copyright laws to protect the authors of books, etc. It is only as part of the book, and as the title of that particular literary composition, that the title is emiuraced within the provisions of the copyright act. It may possibly be necessary in some cases, in order to pro-

'1 Holmes, 185: Fed. Cas. 10,603 (1872). 
tect the copyrighted literary composition, for courts to secure the title from piracy, as well as the other productions of the mind of the author in the book. The right secured by the act, however, is the property in the literary composition, the product of the mind and genius of the author, and not in the name or title given to it. . . . It is a mere appendage, which only identifies, and frequently does not in any way describe, the literary composition itself, or represent its character. - . When the title itself is original, and the product of the author's own mind, and is appropriated by the infringement, as well as the whole, or a part of, the literary composition itself, in protecting the other portions of the literary composition the courts would probably also protect the title. But no case can be found ... in which, under the law of copiyright, courts have protected the title alone, separate from the book which it is used to designate."

In the Encyclopacdia Britannica Case the court took occasion to say:

"Neither the author nor the proprietor of a literary work has any property in its name. It is a term of description, which serves to identify the work, but any other person can with impunity adopt it and apply it to another work or to any commodity, provided he does not use it as a false token. -. If a literary property could be protected upon the theory that the rame by which it is christened is equivalent to a trade mark, there would be no necessity for copyright laws."

In Harper v. Ranous it was held that while, on the one hand, the complainant's copyright of the novel "Trilby" gave him the right to restrain anyone from producing a play presenting scenes, incidents, plot, or dialogue from the said novel, or any substantial part thereof, on the other hand, it gave him no right to restrain the mere use of the name "Trilby" as the title of any dramatic composition which did not present such scenes and incidents. "It is the name in connection with the novel, not the name alone, which the copyright law protects."

Corbett v. Purdy $y^{\circ}$ is a clear-cut decision on a motion for preliminary injunction under the copyright law to restrain the defendants from performing a play of their own composition

'Black v. Ehrich, 44 Fed. Rep. 793 (1891).

"67 Fed. Rep. 904 (1895).

- 80 Fcd. Rep. 901 (1897). 
under the same title as that borne by the plaintiff's play. The court held:

"There is no evidence to show that defendants are publicly performing or representing complainant's 'dramatic composition'. The right secured by the copyright act is the property in the literary composition, and not in the name or title given to it. In no case, so far as this court is advised, has protection been afforded by injunction under the copyright laws to the title alone, separate from the book or dramatic composition which it is used to designate. Whatever rights complainant may have to restrain appropriation by another of the title of his work, on general principles of equity, cannot be considered in this suit, which is a controversy between citizens of the same state, and presents no federal question. Motion for injunction denied."

In Glaser, v. St. Elmo Company it appeared that the copyright of the novel entitled "St. Elmo" had expired in 1908, but that before its expiration the author had authorized a dramatization of it to be made, and the copyright of the play was transferred to the complainant. Shortly after the expiration of the copyright in the novel, the defendants brought out a dramatization of it under the same title, "St. Elmo", using the same plot and incidents, but neither making use of nor attempting to pass it off as complainant's play. The court held that when the norel fell into the public domain anyone was at liberty to dramatize it and to call his dramatization by the name of "St. Elmo", and refused to grant the injunction.

The latest case touching the question is Atlas Mantufacturing Company v. Sireet $\mathcal{E}$ Smith, ${ }^{8}$ in which the complainantsappellees, Street \& Smith, sought to restrain defendants from using in motion pictures or otherwise the name "Nick Carter", which complainants used as a general name to characterize detective stories published by them. They based their property rights upon a registered trade mark and long-established trade name, but Judge Van Valkenburgh, in the course of his opinion, took occasion to inquire what the complainants' standing would be under the law of copyright with respect to the title, and used the following language:

\footnotetext{
' 175 Fed. Rep. 276 (1909).

- 204 Fed. Rep. 398 (1913).
} 
"So the copyright of a book does not prevent others from taking the same title for another book, though the copyright has not expired; and on the expiration of the copyright of a novel any person may use the plot for a play, copy or publish it, or make any other use of it he sees fit. In such case, where one writes and copyrights a play based upon a novel, and bearing the same title as the novel, he cannot prevent another from giving the same title to an entirely different play which has been constructed from that novel."

In England also it is will settled law that the titles of books or other works are not copyright. The case of Welden v. Dicks," which held otherwise, was overruled by Dicks v. Yates, ${ }^{10}$ as pointed out by Lord Justice Lindley in Licensed Victuallers Newspaper. Company v. Bingham. ${ }^{11}$ And to the same effect are the remarks of Mr. Justice Eady, in the late English case of Crotch v. Arnold:12

"It is claimed that the plaintiff's copyright has been infringed because the title of the defendant's book ["The Cottage Homes of England'] is the same as that of the plaintiff's, but on that point the law must be treated as settled, and settled many years ago, in Dicks v. Yates. This case has always been treated by textbook writers and others as settling the law. I think, therefore, that the plaintiff is not entitled to succeed."

On the other hand, it is equally well settled, both in the United States and England, that where a man "passes off" a work under the name or title of another man or another man's work, it is a common law fraud, subject to redress by ordinary common law remedies, wholly irrespective of any of the conditions or restrictions imposed by the Copyright Act. This is the basis of the decisions in the series of "Webster's Dictionary" cases, under the so-called doctrine of "secondary meaning rights" attaching to a title. ${ }^{13}$ As the term "secondary meaning right" implies, it is essential that the work shall have acquired a public reputation, for otherwise no one could be deceived; and moreover, it must be shown that the defendant has in fact acted

I. R. 10 Ch. Div. 247 (1878).

"I. R. 18 Ch. Div. 76 (188r).

עL. R. 38 Ch. Div. 142 (1888).

${ }^{12} 54$ Solicitors' Journal, 49 (1909).

"See especially Merriam v. Ogilvie, 349 Fed. Rep. 858 (1907); 159 Fed. 
so as to lead the public to suppose that his publication is the same as the plaintiff's, in such a way as to damage the plaintiff by making his work less remunerative. ${ }^{14}$ But given these three factors, - public reputation, deception, damage,-a court of equity will ordinarily grant relief by prohibiting, not necessarily all use of the name, but merely its unqualified, unexplained or misleading use. Thus, in the Webster's Dictionary cases, the right of the defendants to publish the 1847 edition upon which copyright had expired, and to call it "Webster's Dictionary", was fully recognized by the court, but they were enjoined from issuing deceptive advertisements and circulars and otherwise attempting to pass off their reprint as the later revised edition of the plaintiffs.

Such protection of course can usually be applied only to certain kinds of works, such as periodicals, dictionaries, encyclopaedias, and the like, when the name has so long been used to designate the production as to have become identified with such particular publications as denoting their origin, and when the unexplained use of such name by another publisher, having no connection with the place or name, can have no purpose except to deceive purchasers. ${ }^{15}$ The same rule is applied in the case of patented articles upon which the patent has expired. ${ }^{10}$

The present law, therefore, is that titles of books are not as such subject to protection under the copyright laws of either the United States or Great Britain. However, equity acting to restrain "unfair competition" will prevent the use of these titles in a misleading manner: 17

Herbert A. Howell.

Library of Congress, Washington, D. C.

Rep. 638 (1908); 170 Fẹd. Rep. 167 (1909); and Merriam v. Szalfield, 198 Fed. Rep. 369 (I912).

"The "Chatterbox" Case, Estes Y. Williams, 2I Fed. Rep. I89 (I884); Social Register v. Howard, 60 Fed. Rep. 270 (1894); Licensed Victuallers $v$. Bingham, supra, note Ir.

${ }^{17}$ Atlas Mfg. Co. v. Street \& Smith, supro, note 8.

${ }^{11}$ Hall's Safe Case, 208 U. S. 554 (1908); Singer v. June, 163 U. S. 169 (1896). And see McLean v. Fleming, 96 U. S. 245 (1877).

st Interest in this subject has been accentuated by reason of the hearings and discussions over the. bill (H. R. 2II37), inspired by the, Webster's Dictionary suits, now pending before Congress, proposing to add 2 clause to the Copyright Act to the effect that upon the expiration of the copyright in books, the titles "shall be forever free to the unrestricted use of the public". 